\title{
Karabus trial - a cautionary tale
}

The phone of attorney Michael Bagraim, who co-ordinated the Abu Dhabi defence of Cape Town's Professor Cyril Karabus on manslaughter and forgery charges has been 'ringing off the hook' as hundreds of now-frightened healthcare professionals seek advice.

'I reckon I must have had 500 calls in the three months since I took on the case, he told Izindaba at the end of November. He said some of the callers (both local and from overseas) were in a similar plight to Karabus, while others simply related 'comparable horror stories.' He cited the current case of a Groote Schuur Hospital nursing sister and client (who wants to remain anonymous), who's been on bail in Dhubai 'for some alleged misdemeanour' for four years - 'without access to money or power. She was a sole breadwinner with children and went to the United Arab Emirates (UAE), to supplement her income. 'I spoke to her yesterday - she's caught in this web where she owes money for her living expenses, her work permit has expired and her case is just dragging on with no end in sight', he revealed. He said the majority of calls hed had were from nurses. Bagraim said that amid the major publicity generated by the Karabus case, a vital issue was being missed: thousands of medical personnel were travelling to foreign and different jurisdictions without sufficient preparation or in the naive belief that similar human rights protections to those they knew at home pertained.

He said that in a system where 'you don't know what the norm is, you're going to possibly fall foul of it - in all innocence'.

\section{Naïve foreign healthcare workers vulnerable}

'Cyril's case is a good illustration: the moment there's trouble everyone shrinks away and yoưre left standing alone. Nobody comes forward, not the agency, the hospital or even your fellow doctors. If Cyril didn't have access to certain individuals, he would have withered away and died ... been washed into the system and never heard of again.' Bagraim said he made his living 'firing people for gross negligence, but you don't incarcerate and put them through the criminal justice system. In any other 'normal' system if Karabus stood accused of negligence, the family might have sued the hospital and if they won, received a damages settlement. The Medical Protection Society (MPS) would kick in. 'Yet here he was left high and dry with absolutely no coverage. If it wasn't for his family working around the clock to get the story known and do whatever it takes to ensure a decent defence, we wouldn't be where we are now', he emphasised. He revealed that for the first three weeks he and Karabus (the two are related by marriage), had taken a 'reasoned decision' to keep quiet. 'We thought the
UAE authorities would see the folly in it (as in potentially scaring away some of the $97 \%$ of foreign healthcare professionals upon whom their system relies) and send him home. Bagraim cited anecdotal evidence from his callers including an ambassador's children (a boy and girl) being arrested for dining together at a restaurant (they were unable to produce their IDs), a doctor carrying anti-inflammatory drugs being arrested and a foreigner whose vehicle was crashed into from behind by a local, being arrested upon arguing.

\section{'Accept liability, move on' - attorney's advice}

'It all runs on access to power, not so much the law. Often the best way forward is to accept liability and move on. He warned medical professionals planning to take a locum or set up practice in foreign climes that 'they cannot rely on life as they know it in South Africa', and advised: 'Do your homework, get the paperwork straight, learn about their system, get back-up in place. He said that in a system where 'you don't know what the norm is, you're going to possibly fall foul of it - in all innocence'. Bagraim praised the Western Cape chief in the Directorate of International Relations and Communication (DIRCO), Michael Canham, as a 'tower of strength' in kick-starting help for Karabus via his Pretoria counterparts and the Abu Dhabi consulate. Bagraim said he initially hit an official brick wall, even approaching the Australian government (who promised to do what they could, provided the South African government approached them first). He firmly believed there was 'no value to your citizenship unless you can rely on your government in situations like these', citing the United States, where 'all hell would break lose if something like this happened to one of their own'. 'I want to know that whether I'm in Mauritius, Israel or the UAE, that when I hit a snag, the first person I can turn to is my embassy or consulate and that they'll do all they can to ensure my rights are protected. I sometimes wonder whether we have the wherewithal,' he said, adding that appointing politicians instead of career foreign diplomats was perhaps to blame. Often such matters were treated as a mere irritation, and because the UAE rendered it a criminal matter, it was 'the easiest thing, to hide behind a political protocol of non-interference'.

\section{Where are the advisory workshops?}

The South African Medical Association (SAMA) added its cautionary voice to Bagraim's, emphasising that the UAE was 'heavily dependent' on foreign doctors to support its healthcare system. Karabus' arrest 'laid bare' the potential risks attached to working in foreign countries. It warned its members to 'think carefully' before working in the UAE and suggested a global boycott of locum skills in countries 'which treat health professionals in such a manner. SAMA chairperson Dr Mzukisi Grootboom, Vice 
Chairperson Dr Mark Sonderup and Chairperson of the Public Sector Doctors Committee, Dr Phophi Ramathuba, added in a joint statement that the 'disgraceful' episode highlighted just how financially challenged those who worked in the Public Sector were left upon retirement. In spite of the Occupation Specific Dispensation (OSD), having improved public sector packages, they remained below par. 'If people dedicate their lives to caring for the disadvantaged and poor, the least they should have is a certainty of security in their future they said. Bagraim suggested that either SAMA or the Medical Protection Society (or both), conduct workshops for doctors planning to relocate or do locums in high-risk foreign countries.

\section{Chris Bateman}

chrisb@hmpg.co.za

S Afr Med J 2013;103(1):13-14. DOI:10.7196/SAMJ.6584 